\title{
The Magnificent
}

Ambersons

A RECONSTRUCTION 
HOLLYWOOD'S MOST AMAZING CITIZEN NOW BRINGS YOU HIS SUCCESSOR TO "CITIZEN KANE"

THE STORY OF A WOMAN IN LOVE-FROM THE FAMOUS PUITZER PRIZE NOVEL BY BOOTH TARKINGTON
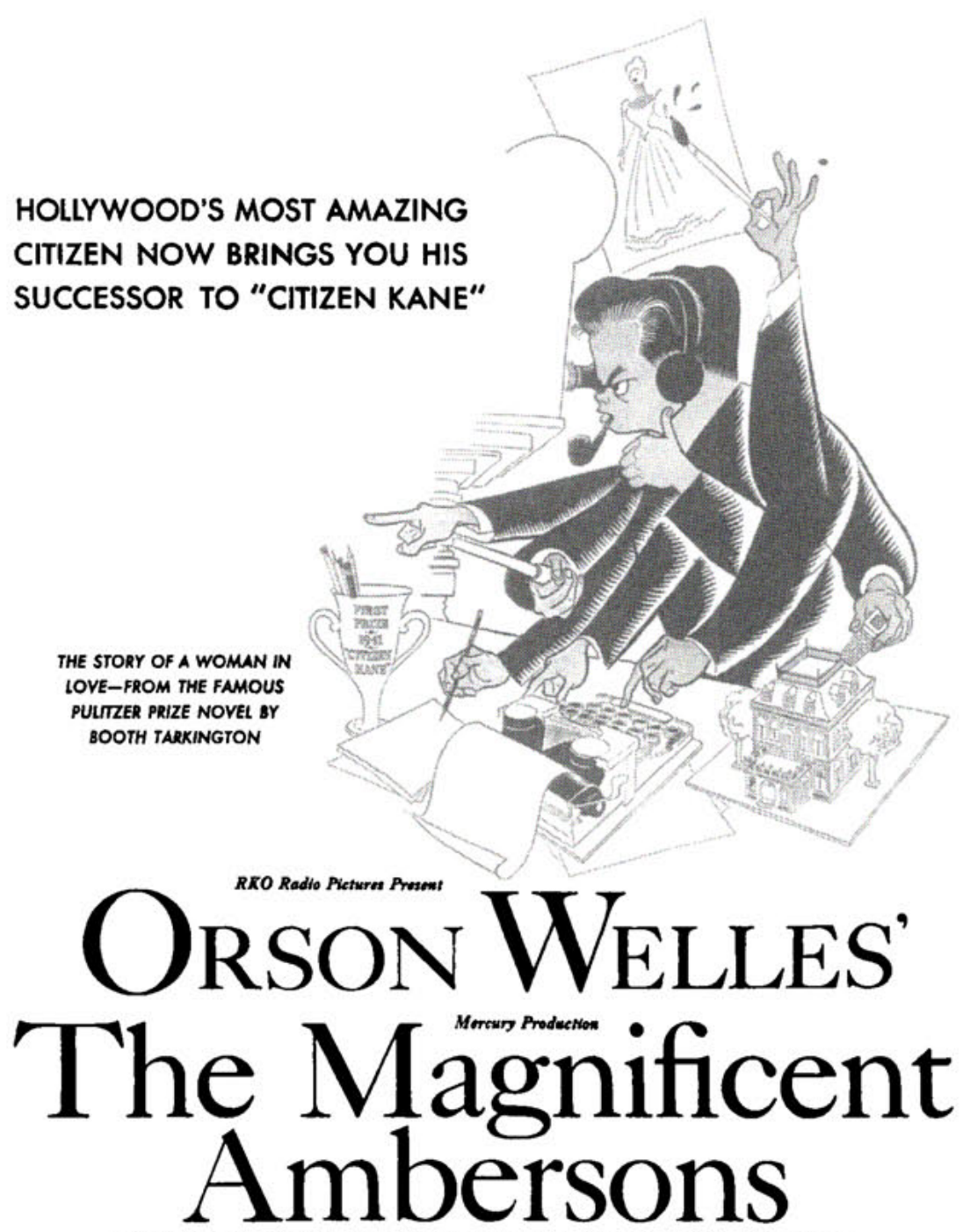

With JOSEPH COTTEN - DOLORES COSTELLO - ANNE BAXTER - TIM HOLT AGNES MOOREHEAD - RAY COLLINS - ERSKINE SANFORD - And RICHARD BENNETT Sereen Ploy, Praduction and Direction by Orson Welles 


\title{
The Magnificent Ambersons
}

\author{
A RECONSTRUCTION
}

Robert L. Carringer UNIVERSITY OF CALIFORNIA PRESS

Berkeley Los Angeles Oxford 
The publisher gratefully acknowledges the contribution provided by the General Endowment Fund of the Associates of the University of California Press.

This book is a print-on-demand volume. It is manufactured using toner in place of ink. Type and images may be less sharp than the same material seen in traditionally printed University of California Press editions.

University of California Press

Berkeley and Los Angeles, California

University of California Press

Oxford, England

Copyright () 1993 by The Regents of the University of California

Library of Congress Cataloging-in-Publication Data

Carringer, Robert L.

The Magnificent Ambersons: a reconstruction / Robert L. Carringer

p. $\mathrm{cm}$.

Includes bibliographical references.

ISBN 0-520-07857-8 (cloth : alk. paper)

1. Magnificent Ambersons (Motion picture) 1. Title.

PN1997.M25433C37 1993

$791.43^{\prime} 72-\mathrm{dc} 20$

CIP

Certain materials included in this book (cutting continuity, photographs, sketches, business documents, and other items) are copyright RKO Radio Pictures, Inc. 1942, renewed RKO Pictures, Inc. 1969. New materials in the book are copyright 1993 by The Regents of the University of California.

Printed in the United States of America

The paper used in this publication meets the minimum requirements of ANSUNISO Z39.48-1992 (R 1997 ) (Permanence of Paper). 
